\title{
Open and Distance Education in a Digital Age
}

\author{
Adnan Qayyum and Olaf Zawacki-Richter
}

\section{Introduction}

Open and distance education is changing. Distance education (DE) in higher education is changing in size, location and shape. Generally speaking, the size of distance education is growing in many parts of the world as more people are enrolled in DE offerings. In Brazil, there was an enrolment growth of $900 \%$ from 2000 to 2010 (de Oliveira Neto and dos Santos 2010). In Russia and Turkey, nearly 50\% of all higher education students enrolled in open or distance education programs (Zawacki-Richter et al. 2015). The number of people enrolled in DE courses and offerings may have never been higher in many countries.

The size of DE is growing on the supply side as well as the demand side. On the supply side, more DE is being offered by institutions that have conventionally offered DE and by new entrants. Historically, distance education was the mandate of single mode institutions that specialized in distance learning provisions, or dual mode universities that provide on-campus programs and offered DE from a continuing education department. Dual mode institutions that offered DE were universities and colleges that made "access" an important principle in their university mission. Their distance education departments were usually tucked away in continuing education, extension or adult education departments. The single mode universities were either distance teaching universities, like the University of South Africa or the FernUniversität in Germany, or open universities like the Open University in the United Kingdom or the Korean National Open University. From their start in the 1960s and 70s open

\footnotetext{
A. Qayyum $(\varangle)$

Pennsylvania State University, State College, PA, USA

e-mail: adnan@psu.edu

O. Zawacki-Richter

Carl von Ossietzky Universität Oldenburg, Oldenburg, Germany

e-mail: olaf.zawacki.richter@uni-oldenburg.de
} 
universities represented a novel educational organization. They increased access to higher education by opening the admissions requirements for entering universities. This was combined with the flexible delivery of distance education. Single mode open universities have continued to grow over the decades. They constitute most of the world's largest "mega-universities" (Daniels 1996, p. 8), universities which enrol over 100,000 students. The demand for open and distance learning opportunities especially in developing countries is enormous. Hence, new open universities have been established in more recent times like the Open University of Nigeria (in 2002), the Arab Open University (in 2002), the Cyprus Open University (in 2004), and the Wawasan Open University in Malaysia (in 2006). The Open University of Nigeria has grown exponentially, serving over 200,000 students today.

The size and location of DE is changing as an increasing number and type of institutions are offering DE programs and courses. Within many conventional open and distance education institutions, the number of DE offerings has increased, as supply follows demand. But now more residential universities, as a whole, are offering DE courses and programs. Historically, dual mode universities usually excluded institutions that prided themselves on their exclusiveness. Elite universities like Tshingua or Stanford were elite partly by their admissions and price barriers. They had marginal, if any, interest in the access mission of DE. Now dual mode institutions that prided themselves on their exclusiveness are increasingly offering online courses. In Europe, over $80 \%$ of higher education institutions are offering online courses, where the course is delivered primarily to geographically distant students (Gaebel et al. 2014, p. 7). In countries like Brazil, Malaysia and the United States the growing demand for DE has seen a growth in private sector DE providers. The number and type of DE institutions continues to grow. DE is offered from more institutions in more locations than ever before.

The shape of DE is changing. A common format for a DE offering is a course delivered by a university. But it is certainly not the only format. DE has always been offered in more formats than conventional education. Fundamentally, DE has been education that uses information and communication technologies (ICTs) to overcome the separation between learners and educators. Freed from the need to be in the same location at the same time, usually a classroom, DE offerings have ranged from self-paced independent study, where students learn mainly on their own, to cohort-based collaborative courses. These are delivered either asynchronously or synchronously depending on learning goals and technologies available. Historically, DE providers have used successive generations of ICTs from print correspondence and postal delivery to radio broadcasts, television, videoconferencing, computer conferencing and the internet. New formats for DE offerings have continuously emerged using new technologies and novel design. Massive open online courses (MOOCs) are the most high-profile recent example of a novel format. Large open access courses are certainly not new in DE history, nor is providing educational offerings that have the option of accreditation or not. Large scale open educational programs have been offered for decades like the national radio farm forums in Canada in the 1940s, the language education radio broadcasts offered in Kenya and Lesotho in the 1980s (Perraton 2006), Funkkolleg educational broadcasts for certificates in West Germany, 
formal educational courses via television broadcasts by the Central China and Radio and Television University, and the nonformal education programs of British Broadcasting Corporation telecasts. Since the advent of the internet and mobile technologies there seems to be an acceleration of different formats. As the world is increasingly connected to the internet via various devices, online education in multiple formats has captured the interest of students and educational institutions. The increased use of "blended", "flipped", "massive", "distributed", "mobile", "flexible", and "nonformal" learning or education are often manifestations of different DE formats. The shape of DE continues to broaden.

\section{The Purpose and Structure of This Book}

Growth in education enrollments and use of digital ICTs in education do not show signs of slowing. In the short term these trends should continue to affect the size, shape and location of DE. Certainly, open and distance education is changing, and there has been much research on how digital ICTS are affecting DE teaching, learning, design and even management issues. But we do not know how these changes are affecting different countries. There is a lack of DE research on macro level issues about DE systems (Zawacki-Richter and Anderson 2014) including: the relationship of DE with higher education systems in various countries; the organization and structure of higher DE systems; how changes in DE are affecting open universities; what are major challenges that DE providers are encountering? This book is the first of two volumes aimed at describing how ODE is evolving to reflect the needs and circumstance of the national higher education systems in these various countries. A second goal is to compare how DE is organized and structured in various countries.

\section{Methodology}

Nations are the focus of these two volumes because educational systems are usually organized according to the nation state. In some places education policies and decisions are made mainly at the local state or provincial level, as we see for Germany and Canada discussed in this book. However, even in such settings, the overall national context is the starting premise of educational policy making (Baker 2009, p. 958). This makes nations an important unit of analysis and measurement for most international and comparative educational work.

Nearly all the nations chosen for these two volumes have a long tradition in DE and have seen substantial changes in the applications of ODE in recent years. Geographical and regional diversity were important in selecting countries. Some countries like Spain, Indonesia and Nigeria have strong DE traditions, but were not included as only 12 countries could be described and analyzed in these two books. Australia, Brazil, Canada, China, Germany, India, Russia, South Africa, South Korea, 
Turkey, United Kingdom, United States have strong DE traditions. Choosing these countries also allowed for describing and comparing DE that affects over half the world's population.

The goal in this book is not just to describe what his happening in different countries but to compare what is happening. Comparison is not a straightforward process. Countries have different social, political and educational histories that must be acknowledged. Comparing requires a tertium comparationis, "a third comparison" or common points of reference, so that countries can be compared with common variables while accounting for different histories, resources and priorities of educational systems (Raivola 1985). The goal in the book is not only to let the reader discover similarities and differences. The goal is to distinguish different approaches and identify models of the relationships between DE and higher education systems.

To create common points of comparison, the authors of each country chapter were asked to address the following guiding questions about DE:

1. What is the function and position of distance education within the national higher education system?

2. Which are the major DE teaching and research institutions?

3. What is the history and past of distance education including online education?

4. What is the relationship between DE and more established and older campusbased, residential institutions?

5. What is the relationship between public and private sector online and distance education?

6. What are the regulatory frameworks for DE? What are important policies for online and distance education?

7. What are estimated student enrollments for online and distance education programs?

8. What are probably important future developments and issues for online and distance education?

\section{Structure of the Books}

The books are organized into two volumes. They are roughly organized by continents, though Russia and Turkey are in both Europe and Asia. The first volume covers Australia, Europe and the Americas and includes chapters from Australia, Brazil, Canada, Germany, the United Kingdom and the United States. The second book covers Asia, Africa and the Middle East and include China, India, Russia, South Africa, South Korea and Turkey. Each volume includes a concluding chapter comparing the countries described.

Experts in DE from each of the 12 countries were invited. All authors have deep experience as DE researchers, practitioners or journal editors of the countries about which they write. Each country is described and analysed from two perspectives. In the main chapter of each country, the authors address the guideline questions in 
their own format. There is no template structure, so authors can share their insights according to their own approaches. After the main chapter is a second section called the commentary. It is written by a different DE expert from that country. These are not critiques of the country chapter. They are commentaries about open and distance education in that country. They are short accounts on DE from the perspective another expert in the country to further validate the results.

In each of the books the countries are presented alphabetically. Chapter 2 in this book is about Australia. Colin Latchem describes how DE in Australia has gone through three historical phases: correspondence education/external studies from 1910 to 1970; distance education from 1970 to 1980s; and open, flexible and online learning from 1980s to the present. Online and flexible learning have changed the size and shape of DE in Australia. The number of students studying at a distance has increased in Australia, from just over 10\% in the 1990s to $18 \%$ in 2013. At the same time nine percent of higher education students are enrolled in multi-modal learning, which includes blended learning, flipped learning and other approaches that allow for taking courses partially off campus. This growth, along with MOOCs and increased connections of formal and nonformal education, is creating something different from "distance education" as it is conventionally understood.

Frederic Litto states that DE offerings in Brazil are fairly recent in any sustained way, despite a few offerings via radio in the 1930s, television in the 1950s and correspondence in the 1990s. 1996 was the key year in the development of DE in Brazil when degrees via distance were given equal status as those earned via face-toface education. From that time, the growth in distance education, particularly online education, came gradually and then suddenly. In 2002, 25 mainly public institutions were offering distance based higher education courses. By 2015, over 300 higher education institutions could offer DE courses and nearly $80 \%$ of them were private institution. There are now over one million undergraduate students alone enrolled in distance education based programs.

Tony Bates describes how Canada has moved very strongly into online education in the past 25 years. In fact, Canada has been an innovative leader in distance education, particularly online education. The first web-based learning management system, WebCT, was created at the University of British Columbia, and the first MOOC was offered at the University of Manitoba. The innovations have emerged predominantly from public institutions as there is very little private sector distance education provision in Canada. There are a couple of single mode public institutions-Athabasca University and Tele-Universite Quebec-and many dual mode public institutions offering online education. There is also no national government involvement in education and no national ministry or department of education. There are, however, several meta-organizations that help foster and coordinate online education.

Ulrich Bernath and Joachim Stöter discuss the changes that have occurred in DE in Germany. There is a long tradition of DE there dating back over 150 years. DE was especially important in the former East Germany where nearly $25 \%$ of all higher education degrees were granted via distance education. In West Germany radio based DE was popular in the 1960s and FernUniverstät—a single mode DE provider-was 
opened in 1975. But changes in DE in the 1990s were affected by the reunification of Germany and the growth in the use of ICTs in all higher education. Of Germany's 427 higher education institutions, only a small percentage offer DE programs. Still, enrollments in distance learning have continued to grow in more recent times, in both degree granting and non-degree granting programs.

Anne Gaskell reminds us that the late Nelson Mandela was a distance education student of a university in the United Kingdom. While in prison during apartheid South Africa, he studied law through the University of London's International Programmes, a distance and flexible learning program that has been operating for over 150 years. The UK has a long rich tradition in DE, including being the country to start the first Open University. The initiative gave rise to many other open universities throughout the world. More recently, ICT use has grown in higher education in the UK but the Open University continues to be the most important DE institution in the country. Changes in government funding policies are a concern for DE in the UK as is the growing use of MOOCs. In response to the latter, the Open University has created its own MOOC platform and partnership.

Michael Beaudoin provides a long view of DE in the United States. While most discussions in the U.S. are about online education, there is a long tradition of DE delivered by other media over many generations. The U.S. has over 6500 higher education institutions that includes a public, private non-profit, and private for-profit universities. DE has a long tradition mainly with public institutions. With the advent of online education, private non-profits and private for-profit institutions have become involved. Unlike many other countries, the U.S. has a mix of a state and market funded model for higher education. The cost of higher education is a major issue and this has affected DE enrollments. Online education has grown overall in the past decade, but this has mainly been at public and private non-profit institutions. Private for-profit online providers have seen enrollments drop in recent years.

\section{Terminology}

As DE has changed shapes, many new terms are used to define activities that are the same as, or overlap with, distance education. Common terms include online learning, e-learning, distance learning, open learning, blended learning and flexible learning (see for example Orr et al. 2017). The numerous terms can cause conceptual confusion. DE and online education overlap but not all distance education is online and not all online education is via distance. Some have argued that online education originates separately from distance education, with the former more focused on collaborative learning while the latter still has a focus on independent learning (Garrison 2009). This is not a book about only on online learning or e-learning, though they are discussed by authors when they overlap with distance education. Guri-Rosenblit (2005) argued that distance education in most higher education systems is not delivered through the new electronic media, and e-learning in most universities and colleges all over the world is not used for distance education purposes. In this book authors 
address whether this is the case. In many countries, online learning or e-learning are a small if growing aspect of DE. But even here, the fundamental experience of distance education still matters - the separation of the student from the instructor (Kanuka and Conrad 2003). While physical distance may matter less in some countries, it is still an important reality for people in many countries. Indeed, the authors identify that the terms distance education and open learning have a different meaning in, say Russia and Turkey, then they do in Brazil or the United Kingdom. As such, distance education, in all its varieties and platforms, is the focus of these two books.

\section{References}

Baker, D. P. (2009). The invisible hand of world education culture. In G. Sykes, B. Schneider, \& D. N. Plank (Eds.), Handbook of education policy research. New York: Routledge.

Daniels, J. (1996). Mega-universities and knowledge media. London: Kogan Page.

de Oliveira Neto, J. D., \& dos Santos, E. M. (2010). Analysis of the methods and research topics in a sample of the Brazilian distance education publications, 1992 to 2007. American Journal of Distance Education, 24(3), 119-134. https://doi.org/10.1080/08923647.2010.497325.

Gaebel, M., Kupriyanova, V., Morais, R., \& Colucci, E. (2014). E-learning in European higher education institutions. Belgium: European University Association.

Garrison, R. (2009). Implications of online learning for the conceptual development and practice of distance education. Journal of Distance Education, 23(2), 93-104.

Guri-Rosenblit, S. (2005). Distance education and e-learning: Not the Same thing. Higher Education, 49(4)467-493.

Kanuka, H., \& Conrad, D. (2003). The name of the game: Why "Distance Education" says it all. Quarterly Review of Distance Education, 4(4), 385-393.

Orr, D., Weller, M., \& Farrow, R. (2017). Models for online, open, flexible and technology enhanced higher education-Results of a global analysis. Presentation at the World Conference on Online Learning. Toronto: International Council for Open and Distance Education.

Perraton, H. (2006). Open and distance learning in the developing world (2nd ed.). London: Routledge.

Raivola, R. (1985). What is comparison? Methodological and philosophical considerations. Comparative Education Review, 29(3), 362-374.

Zawacki-Richter, O., \& Anderson, T. (Eds.). (2014). Online distance education-Towards a research agenda. Athabasca, Edmonton, Canada: Athabasca University Press. Retrieved from http://www. aupress.ca/index.php/books/120233.

Zawacki-Richter, O., Kondakci, Y., Bedenlier, S., Alturki, U., Aldraiweesh, A., \& Püplichhuysen, D. (2015). The development of distance education systems in Turkey, the Russian Federation and Saudi Arabia. European Journal of Open, Distance and E-Learning, 18(2), 113-128. 
Open Access This chapter is licensed under the terms of the Creative Commons Attribution 4.0 International License (http://creativecommons.org/licenses/by/4.0/), which permits use, sharing, adaptation, distribution and reproduction in any medium or format, as long as you give appropriate credit to the original author(s) and the source, provide a link to the Creative Commons license and indicate if changes were made.

The images or other third party material in this chapter are included in the chapter's Creative Commons license, unless indicated otherwise in a credit line to the material. If material is not included in the chapter's Creative Commons license and your intended use is not permitted by statutory regulation or exceeds the permitted use, you will need to obtain permission directly from the copyright holder.

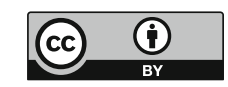

